\title{
Claims For Unaccrued Rent in Bankruptcy
}

$W^{\text {HEN the tenant of business property is in bankruptcy, the two }}$ his creditors. The bankrupt-tenant is less concerned. ${ }^{1}$ By hypothesis he has given up. He cannot go on, either at the old stand or elsewhere, and even if he wishes to continue in the same place and under the same conditions as before, he is quite aware that it will be a piece of rare good luck if he manages to do so.

The landlord is in somewhat of a dilemma in regard to the unexpired portion of the lease. If the bankrupt should rehabilitate himself and fulfill the hopes that created the principle of discharge in bankruptcy, the landlord might expect a contimuing income from future accruals of rent. If that is unlikely-and the fact of bankruptcy at once reduces its probability-he has still a choice of courses. The demand for his premises may be high, in which case he has not only suffered no loss but he even has a chance of profiting by the bankruptcy. He might, then, well be willing to omit from consideration any future rent from the bankrupt and look for a solvent tenant. Or else the demand may be slight. That is to say, his property has decreased in market value since the lease was originally made and he would certainly like both to get his property back and be compensated for the loss.

The choice is a difficult one and he must make it at the time of the adjudication. And his difficulty is increased by the chaotic condition of the bankruptcy law on this point which makes it very doubtful whether he has any such choice and whether he is not required to resume possession-if his lease justifies it-and forget the future rent, or is compelled to allow his bankrupt tenant to continue in possession with the result that he must wait for the next default to eject him.

There are two ways of dealing with this problem. One is that of really trying to find out what the common situations are and to deal with these situations on the theory that the legal machinery is meant to minimize economic fiction and assist economic readjustment. The other is to treat law as a form of mathematics or perhaps of theoretical physics. We take the rules governing the relationship of landlord and tenant and the rules of bankruptcy, formulate them as abstractions and

1 The tenant is, of course, concerned to a substantial extent, if he proposes to continue business and wishes to be relieved of a burdensome lease. This situation will be specially discussed in the second part of this article. 
deal with them as formulas. This has been the traditional method and the formulas which are used as the basis of calculation are regularly claimed to have historical warrant. Evidently even if they were in fact ancient, that would be irrelevant on the supposition that the law is dealing with people living now, but when the historical claim is examined, it often turns out that the modern formula is not the ancient one at all.

In the following pages we shall first attempt to set aside ancient history and mathematical legal constructions and ask ourselves what the landlord and tenant in practice conceived their relationship to be. We may say that the landlord thinks of his land as a source of income, an investment which brings him a return, not differing in kind from other investments. In that, for once, ancient history supports us, because, as the brilliant researches of Jouon des Longrais have shown, leasehold interests were among the chief sources of capital investments in a society that was just beginming to feel the need of capital investment.

The tenant, on the other hand, thimks of his obligation to pay rent as one of his current expenses. It is counted as forming part of the cost of running his business and is often a substantial part of that cost, so that a profit must be earned on that as well as on other costs, if he is to think of himself as prosperous. It is a recurring charge, but it is not different from the amount due on notes, on bills for merchandise, on wages and salaries. He will in an emergency seek to defer payment on one as well as on another and ordinarily-since distress has generally been abolished in the United States-no one of these creates any lien on his person or his goods. If he fails to pay his rent, he may be sued and perhaps ejected. If he fails to pay his bills of any kind, he may be sued and his property - any property-seized in execution of the judgment. Whatever mimute and subtle discriminations courts find between his rent-obligations and his other debts, it is not apparent that the rentobligor-the tenant-feels any difference.

If the actual situation, so conceived, were the basis of the bankruptcy rules in regard to it, it is evident that the obligation to pay a fixed amount as rent for ten years to cone would be no different from an obligation, let us say, to purchase certain goods from a manufacturer for the next ten years. In either case, the bankrupt may or may not have disabled himself from performing the contract just as he may, at bankruptcy or at any other time, announce his intention not to perform. In the case of the manufacturer he would be considered as having breached his contract by anticipation and to owe damages for so doing. Certainly no reason based on common sense or every-day business dealing can be found which justifies treating the landlord differently. 
But the law of bankruptcy - which has its roots in ideas and practices remote from the common law-has, in this respect as in others, been compelled to build on common law foundations. And as the relation of landlord and tenant is one of the most perverse, complicated. and irrational of all common law situations, it is hardly surprising that the result is confusion when we seek to reconcile it with the realities of the situation, and that it becomes definite and orderly, only if wefrankly abandon experienced reality and play with the counters fur-nished us by an eminently non-Euclidean legal geometry.

Suppose we do so. What are our conceptual factors? A lease is a demise of a term. It is the grant of an interest in land-a less than freehold interest which the lessee or tenant owns. He is possessed but not seised of the land. Out of the land there arises the obligation to pay rent. This obligation was not directly based on use and occupation but on the ownership of the term. The relationship was, one inight almost say, in a state of very delicate equilibrium. Breach of the covenants. of the lease entitled the landlord to re-enter if it is so provided, as it usually is, and if he did re-enter, the lease and the obligation to pay rent disappeared. The same was true of abandonment by the tenant followed by re-entry. On the other hand, eviction, if the tenant did in fact leave the premises, ended the lease. A great many things were required to make quite sure that there was an eviction, an abandonment: or a re-entry.

Now, if we put these formulas together and add, subtract and multiply them in accordance with the rules of our game, what. happens? The tenant is in bankruptcy. That is, either of itself $^{2}$ or by special provision, an abandonment or a breach of the lease, entitling. the landlord to re-enter. He does so. Then the relationship ceases and no rent can thereafter possibly be owed. Or he does not do so. Thenthe covenant has not been effectively breached, or the abandonment is. incomplete, and no rent has yet accrued.

But suppose the landlord has especially provided in his lease that in case of bankruptcy, the obligation to pay the rent shall continue to. exist, even though the premises are abandoned and the landlord reenters? That must, it is held, be disregarded because the landlord cannot provide that a lease shall not be a lease. To give force to what is provided is to say that a lease is a contract, like any other contract, precisely what the rules of our legal mathematics forbid us to do. If a lease is a contract, and to the extent that a lease is a contract, it is one, we are told,

2That bankruptcy is of itself the breach of a lease for land is still an openquestion as far as the decided cases are concerned. Nor is a "bankruptcy clause"an unfailing provision in leases. 
so bound up with the relationship of landlord and tenant, that only after the fundamental rules of that relationship are satisfied, can we consider the contractual bonds between the parties.

This is in effect the result to which, in some jurisdictions, courts have come by making their calculations in accordance with the rules. Whether it is good for the landlord or the tenant, is apparently irrelevant. It is generally good for the creditors, who thereby reduce competition for the fund by just so much, but the creditors' advantage is not the basis of the doctrine. And it seems to be even more irrelevant to note that no part of this elaborate structure, which, as is stated, constitutes the relationship of landlord and tenant, was present to the minds of either landlord or tenant when they entered into that relationship.

All this calculation depends on taking a moment of time and treating it as a fixed and immovable terminus. This, let us say, is the date of the petition, provided it is followed ultimately by an adjudication. A claim which on the day of petition-we are at least not required to count hours or minutes-did not exist as yet, is not provable, and the test of existence under section 63 is whether the liability is absolute on that date, even though no action could then have been brought on it.

This expression "absolutely owing" has been something of a puzzle. It seems to mean any debt which except for the element of time would be actionable at once. The consideration has already been furnished.

Now let us first take the situation in which there is no provision in the lease that specially regulates the tenant's liability in the event of bankruptcy. The lease still subsists. The rent that under the terms of the lease is not payable till the next month is obviously not payable now. Nor can it be said to be absolutely due although not payable now, because it is not merely the lapse of time which will make it payable but the continued furnishing of the consideration. The landlord has something to do under the lease. He may be willing and ready to do it but he has not yet done so.

It seems curious that so many cases should have thought it worth while to labor this point extensively. Nearly all the cases which are cited to prove that the landlord cannot consider unaccrued rent claims at all, are merely solemn repetitions of the logical truism that what cannot be demanded at a certain moment of time is not due then.

But suppose we have a second situation, in which the lease does say something about the tenant's bankruptcy. It provides, let us say, that bankruptcy may be treated by the landlord as a breach of the lease's covenants and that the landlord may re-enter and treat all future rents as immediately due. Everything depends on the moment when the landlord re-enters. If he re-enters on the day after the petition, the 
future rents-assuming the validity of the provision-are not due till the day after. They could not have been sued upon till the day after. They were, therefore, not due nor provable on the day of the petition.

As a problem in mathematics, this solution is impeccable and we can understand the gratified triumph of the court when it reached this solution in such a case as In re Service Appliance $\mathrm{Co}^{3}$ Of course the court would have been hard put to it, if, as is not at all impossible, the landlord enters on the very day on which the petition is filed. We may well suppose in fact that any landlord would wish to enter as soon as possible, and it is generally only ignorance of the filing of the petition or physical impossibility that prevents this from becoming the regular thing. It seems a little too bad that substantial rights should be made to depend on such logical pedantry.

Evidently, we should be on a solider basis if we applied the rule of Kothe v. Taylor Trust Co. ${ }^{4}$ and made all such acceleration clausesall provisions which made future rent due by the landlord's act of terminating the lease-void as a penalty. In that case it makes no difference whether the landlord entered" on the day of the petition or later. But if we continue to reserve this point, it does seem somewhat absurd to make the exact moment of time so important. Since we are dealing with these semi-abstract calculations, would it be so difficult in a system that thinks nothing of "relating back" and of freely employing "as of's," "as if's," "as though's," to treat any entry of the landlord occurring within a reasonable interval as occurring on the day of the petition? We should then be compelled to face the question of the penal character of the provision.

That it is frequently penal there can be no question. But clearly it is not necessarily so. If the residue of the term is small, the future rents may be less rather than more than the damages caused by the breach. There are the expenses of preparing the premises for a new tenant, the expenses of getting a new tenant as well as the likelihood of being compelled to accept a lower rent. It might not be impossible to decide when the provision is penal and when not, and to avoid the provision only when its penal character is fairly apparent.

It is curious to note that in that part of the common law which "has not forgotten Coke" unmistakable penal clauses, so far from being void, were regular and quite proper. ${ }^{5}$

3 (N. D. N. Y. 1930) 39 F. (2d) 632.

4 (1930) 280 U. S. 224.

5 Brendloss v. Philips (1602) Cro. Eliz. 895; Stancliffe v. Clarke (1851) $7 \mathrm{Ex}$. 439; Co. LITT. 162b, \$240; WoOdFall, LaW of LaNdLORd aNd TENant (22d ed. 1928) pp. 499 et seq. 
But suppose a third situation in which the lease deliberately refrains from a penal clause, evades the fine mathematics previously mentioned and provides that the lease shall automatically terminate at bankruptcy at the date of the petition and that the landlord shall thereupon be entitled to whatever damages he can establish by reason of the anticipated breach of the covenant to pay rent for the balance of the term. This, it would seem, avoids the difficulties mentioned. The claim is not for rent that will accrue in the future but for damages that accrue now. The landlord need do nothing to end the term and cannot, therefore, by delaying a day, prevent a claim from arising on the day of the petition. Nor is this simply an indirect way of proving a claim for rent. The damages are to be proved, as damages generally are proved, and there is no greater difficulty in liquidating this claim than any other claim for breach by anticipation. The amount of the rents which would have accrued is simply one of the factors to be considered in the calculation. It is quite unlikely-unless the balance of the term is very short-that the damages will quite reach that amount.

It is hard to see why a landlord should ordinarily object to this solution. He has his property back and his claim for damages, considered as a present loss, is in exactly the same position as any other creditor's claim. The acceleration clause which leases so frequently contain-unless they are honestly meant to be a measure of damagescan only have the effect of giving the landlord a distinct preference.

Although in Kothe v. Taylor Trust Co. the court held this type of clause void as a penalty, it must be noted that it would usually not be a penalty in fact. The penalty would exist only when the amount of the rents wonld exceed the actual damages. But the landlord will get his claim for rent paid only by a dividend which normally will be only $5 \% .^{6}$ In other words, in the average case the landlord will get only one-twentieth of the rents which wonld have accrued and this amount is not likely to be more than the actual damage caused. However, he would get a much higher proportion of his real claim than other creditors and thus would obtain a preference.

The only situation in which the landlord would reasonably and legitimately prefer not to be compelled to prove for his damages and thereby terminate the lease would be in those cases in which he has reason to believe that the tenant ineans to continue after bankruptcy and will be solvent. This must necessarily be rare, but in the trough of the economic cycle it might well happen. It was freely stated that

${ }^{6}$ In 1928 , the percentage of obligations paid to unsecured creditors was $6.3 \%$; in $1929,5.53 \%$; in $1930,7.37 \%$; in $1931,5.31 \%$; in $1932,4.71 \%$. 
certain chain stores desiring to reorganize, found their still subsisting long term leases a heavy burden. Evidently if they could get rid of them by going into bankruptcy-insolvency under the N.B.A. definition can almost be taken for granted in a tinse of general economic depression-they might be able to get new leases at much more advantageous terms.

There is no good reason why a landlord should be compelled to resume possession if he thinks fit not to do so, and there is no reason why this third situation which is predicated upon an automatic termination of the lease by bankruptcy, should not include a condition subsequent which permits the landlord to waive his claim for damages and reinstate the lease. The claim for damages will none the less be absolutely due and owing on the date of the petition.

Accordingly, if the situation is merely that of a tenant who intends to use bankruptcy to shake off burdensome obligations, but has no intention of ceasing his business if he can help it, the landlord can, if the lease is carefully drawn, prevent this from happening.

It is true that the rent reserved nnay have been exorbitant. That is likely to be true of any contract made at peak prices and perhaps more likely to be true of rents, because of the monopoly character of land. But our law has not recognized the primciple of lesion, except in equity, when it is sought to enforce unconscionable contracts, and we have not arrived even in economic doctrine at any satisfactory system of periodically revising economic relations in accordance with the fluctuations of economic values. There is no reason why contracts should not be enforced as they are made-with certain exceptions, to be sure-and the law should provide that it may be done.

But we might properly recognize the fact that formal contractsleases and the like-do not in fact represent the real intention of the parties. Few leases are made with full contemplation of the situation in bankruptcy, and instead of making rights depend on the signatures of the parties of the first and second parts to a printed form, it would be better to make general rules for leases and require those who wish to make their situation an exception, to contract themselves out of the usual provisions.

These general rules nuust take into account-indeed they should be merely a generalization of the actual facts likely to be found-what would ordinarily best and most equitably adjust the relations of the landlord to the other creditors of the tenant. How that can be done, will be later more fully shown. The landlord may withdraw himself entirely from competition. If he competes, it must be as a real creditor, 
one whose claim depends on loss sustained or consideration furnished. If he has been damaged and to the extent of his damage, he should receive his dividend and no more.

The difficulties, of course, lie in the actual methods of liquidation of his claim. How is it to be done?

The process of liquidation involves an appraisal of the present value of what is in effect an investment in realty. It is not an unusual operation but there is no doubt that it is often carried out in a fashion that has little relation to the process of discovering such values. It is generally by attempting to compromise between the divergent estimates of rival appraisers. If we make it a rule to take the mean, this will soon be consciously or unconsciously provided for in the estimates offered by the appraiser.

To be sure, if there were official appraisers who were arms of the court we should have a slight guaranty of impartiality, but, in view of some recent unpleasant experiences, it is very likely that the impartiality would be challenged by those who are affected adversely by an official appraisal.

In the case of an unexpired term in a lease, it is to the interest of the landlord to value the unexpired term as low as he can, and to that of the trustee, to appraise it as high as he can. The one who knows most about the value-or can learn most about it-is the landlord. Evidently if we can exert pressure on the landlord to induce him to make the appraisal high enough to equal what the term might fetch under normal conditions, that would be a desirable situation. ${ }^{7}$

At present the trustee may if he chooses, assume the lease, if the interests of the estate require it. A lease, even though it imposes burdens-particularly that of paying rent-may be a valuable asset. Men have been known to purchase such leasehold interests and to pay sub-

7 Official appraisers for all the bankrupt's property are provided for by the N. B. A. It cannot be said that the institution has worked satisfactorily, in spite of the efforts to secure impartiality. The inherent weakness of appraisals made on the judgment of any particular person is the difficulty of allowing adequately for the special conditions under which the sale must necessarily be made. It is, of course, conceivable that the liquidation suggested above could be effected by means of this existing machinery of appraisement. Ordinarily, if a leasehold interest is sold as part of the bankrupt's estate, it must be sold as an entirety. In most instances, so far from having any value, it is likely to be a liability. But there is no good reason why for the purposes of determining the landlord's claim, the lease cannot be resolved into soune of its component elements, and the tenant's right of enjoyment be separated from the landlord's claim for rents. The latter can then be dealt with as other claims-always remembering that it is to be taken at its present value, and the former can be appraised and sold as provided for in the Act. It would need a little interpretative boldness to reach that conclusion but not more than bas often been applied to this particular statute. 
stantial sums for them. Evidently in such cases the leasehold is worth more than the accumulated future rents, discounted at their present value, or else the advantage of using the property is particularly great for certain particular persons. This situation, we may suppose, is rare and in fact the trustee generally rejects the lease.

But the fact that he has this power means that the law is quite ready to impose upon the landlord a tenant he has not chosen-to-wit, the trustee-and even anyone to whom the trustee wishes to dispose of it. The ordinary covenant against subletting or assigning would not of itself rule out a transfer by law. If the trustee sells the lease for what it will fetch for a lump sum, whoever buys it will then have the premises rent free, because he has already paid the rent.

Evidently this money is the landlord's. It is in all likelihood much less than the total of the rents he liad expected calculated at their present value. The difference between these two sums constitutes his damages, for which he receives a dividend from the estate, a dividend, which we may repeat, is likely to average about $5 \%$.

This may be liard on the landlord. He loses his term. He receives for the capitalized future return much less in cash than he had originally bargained for and only a small portion of the difference. But he can remedy this situation in great part by bidding in on the term limself. If he really believes that the term is worth more than the other bidders are willing to go, he can easily outbid them. The term has probably more value for him than for anyone else.

And the danger that exists in the analogous situation, such as foreclosure of a mortgage, does not exist here. There, the only bidder is often the mortgagee who regularly bids the debt or less and has a clance of getting the property and a substantial deficiency judgment as well. There is little opposition. But in the case of bankruptcy there is an active opposition present which has a strong interest in raising the price of the remaining term. Suppose a lease had still three years at an annual rental of $\$ 1000$. The present value of the rents if the tenant is solvent is about $\$ 2790$. On a sale in bankruptcy, it may well be that no one will give lialf that, but something can surely be got for it. If the landlord bids a nominal sum, $\$ 100$, or less, any one of the creditors or any outsider will, one may suppose, offer more for a right which only a sliort while ago was worth nearly $\$ 2800$.

All this cannot be managed, under the present act, against the landlord's will. But if lis claim for danages is allowed, he is likely to do better if he consents to this method of appraisal of the residue of the tern than if he insists on the usual one. 
Perhaps the situation can best be presented by a proposed draft of the changes which would be necessary in the Act in order to make this method the usual one.

If the bankrupt is a lessee and if the trustee does not assume the lease, the lessor shall have the following options:

(a) He may declare the lease termimated, waiving all claims for rent not yet accrued except that, besides the accrued rent, the lessor shall also be entitled to the reasonable value of the use and occupation of the premises from the date of the last accrual of rent to the date of the petition in bankruptcy.

(b) He may declare the lease still in force and the lessee still liable for the rents reserved. In this case, the lessor shall have no provahle claim for any rents except for rents already due and for the reasonable value of the use and occupation of the premises from the date of the last accrual of rent to the date of the petition in bankruptcy.

(c) He may both declare the lease terminated and file a claim for the damages sustained by the lessee's bankruptcy. Such damages shall be determined in the following manner:

Within a reasonable time after his appointment, the trustee shall offer for sale for a lump sum, all the interest the lessee had up to the petition in bankruptcy, subject to all the terms of the lease except the covenant to pay rent. Whatever sum the trustee receives for this interest shall be paid over to the lessor. The lessor may then prove in bankruptcy as a creditor for the difference between this sum and the present value of the rents which would have accrued under the lease after the date of the petition in bankruptcy, had bankruptcy not supervened.

The lessor shall have these three options under every lease, unless it is expressiy provided in the lease that any one of these options is waived in advance or unless it is expressly provided that the lease shall absolutely terminate at bankruptcy without entry by the lessor or abandonment of the premises by the lessee.

It is not seriously suggested that the foregoing draft is enactable in precisely the words here given, but it makes the point clear that the acquisition of the tenant's beneficial interest is not primarily intended to add anything to the estate but merely to be a means of liquidating that interest, so that the landlord's danage can be ascertained.

Anticipatory breach is no longer a strange and new radicalism foisted on the law. Perhaps it is too much to say that the concept of anticipatory breach is one at which many lawyers still look askance. Still it is an eminently practical idea, although it fits only with difficulty into a conceptual scheme that usually insists on niceties of place and time to determine the performance of the breach of contracts. If anticipatory breach is admitted, eagerly or reluctantly, the highly realistic considerations that created the idea are just as valid in the case of an unexpired lease as in any other type of contract. Suppose, for example, there had been merely an agreement to make a lease, an agreement enforceable by a suit for damages when breaclied. Evidently, if before the lease was signed, the prospective tenant liad become a 
bankrupt and by so doing or by an additional act of repudiation had made it clear that he would not go on, this anticipatory breach could have been proved as a claim, to be liquidated in the manner prescribed by the statute. Neither in common sense, nor even in any logic based on factual premises, is there any difference between a lease for ten years which is completely repudiated before it is entered on, and one for ten years, of which the last five years are repudiated. To be sure, the accepted doctrine is that the term is a unit and is not to be split into several successive terms, beginning or ending with the point at which rent becomes due. But that is only renewed mathematics, when we have stopped calculating and are talking business.

All that has been so far said has been based on an attempted analysis of the real relation between the landlord, the tenant and the tenant's creditors at the moinent of the tenant's bankruptcy. That situation has been presented to the courts in literally hundreds of cases. It is likely that whenever it is presented much more attention will be paid to these cases than to the economic and social factors even of typical situations. It is, therefore, imperative to consider what may be called the doctrinal aspect of the question. ${ }^{8}$

Max Radin.

SCHOOL OF JURISPRUDENCE,

UNIVERSITY OF CALIFORNIA.

(TO BE CONTINUED)

${ }^{8}$ In the second part of this article, I shall attempt to analyze the cases in which this question has arisen. 